\title{
Keluar Dari "Teks Besar” Gagasan Post-Positivist dalam Studi Hubungan Internasional
}

\section{Ade Marup Wirasenjaya}

Jurusan IImu Hubungan Internasional, Fakultas IImu Sosial dan IImu Politik, Universitas Muhammadiyah Yogyakarta

Ringroad Barat Tamantirto, Kasihan, Bantul 55183

Email:addewirasenjaya@umy.ac.id

\begin{abstract}
The emergence of new perspectives in the International relations study is driven by analysis unit studies which experience a fundamental change in the world of interdependency today. The old unit analysis, which emphasized "great actor" and formal started to be sued. International relations are characterized by the presence of International society which includes issues, actor also new pattern relation which very influences the explanation and description of International relations. Hierarchy of International relations has been yielding to the external problems and internal problems blurred. Post-positivist view of descent proposed as a new analytical tool in International relations which changed drastically. Keywords:positivist, post-positivis, international society, non-traditional issues, Constructivist
\end{abstract}

\begin{abstract}
Abstrak
Munculnya pandangan-pandangan baru dalam studi hubungan internasional didorong karena unit analisis studi mengalami perubahan mendasar dalam interdependensi dunia saat ini. Unit analisis lama yang terlalu menekankan "aktor besar" dan formal kini mulai digugat. Hubungan internasional ditandai dengan kehadiran international society yang menyertakan isu, aktor serta pola relasi baru yang sangat mempengaruhi eksplanasi dan deskripsi tentang hubungan internasional. Hirarki hubungan internasional telah mengalami peluluhan sehingga antara "problem eksternal" dan "problem internal" semakin kabur. Pandangan post-positivist layak diajukan sebagai alat analisis baru dalam hubungan internasional yang berubah drastis.

Kata Kunci:positivist, post-positivist, masyarakat internasional, isu non-tradisional, konstruktivis
\end{abstract}

\section{PENDAHULUAN}

Studi hubungan internasional barangkali merupakan disiplin dalam ilmu sosial yang paling memiliki grand narratives dibanding disiplin lain. Telah lama ilmu hubungan internasional menjadi ilmu dengan teks-teks yang amat besar, tentang peristiwa besar dunia, serta berisi tokoh-tokoh besar dunia seperti pemimpin, negarawan, raja dan kemudian para jenderal yang memimpin sejumlah perang. Seolaholah, yang berperan menentukan dalam hubungan antar bangsa adalah tokoh-tokoh tersebut. Dalam buku Basic Texts in International Relations yang disunting Evan Luard misalnya (Luad, 1992) nampak jelas bahwa yang disebut teks dasar dalam studi ini adalah tentang perang, diplomasi, hukum internasional, negara bangsa dan sistem internasional. Politik internasional diandaikan sebagai arena interaksi dan relasi antara aktor-aktor besar serta ditentukan arahnya oleh narasi-narasi besar (grand narratives) dan dengan model negosiasi yang amat formal. Di luar hal tersebut, studi hubungan internasional menisbahkan fenomena kecil sebagai urusan disiplin lain seperti sosiologi, antropologi atau juga kriminologi untuk urusan kejahatan.

Bukannya tidak penting, akan tetapi terpaku pada "teks besar" membuat ilmu hubungan internasional - 
khususnya di Indonesia - mengalami dekadensi. Ilmuwan hubungan internasional dengan serta merta menuduh "tidak HI" terhadap rekan-rekannya yang mencoba membawa semangat pembaharuan, dengan misalnya memakai perspektif sosiologi, antropologi bahkan teori sastra dalam hubungan internasional. Dunia kini berubah, terutama jika dilihat dari pola hubungan antar bangsa. Batas-batas kedaulatan pada dunia saat ini bukan semata-mata ditentukan oleh aspek geografis, tetapi pada aspek-aspek yang lebih subtil seperti identitas.

\section{PEMBAHASAN}

\section{DARI INTERNATIONAL RELATIONS KE INTERNATIONAL} SOCIETY

Pasca runtuhnya Uni Soviet dan berakhirnya Perang Dingin, konstelasi hubungan internasional mengalami perubahan mendasar. Hubungan internasional tidak lagi dinisbahkan sebagai hubungan antar negara, atau antar aktor-aktor formal yang didefinisikan studi hubungan internasional sebelumnya. Hubungan internasional memasuki fase baru, sebuah fase yang kemudian memunculkan discourse tentang international society (Keohane dalam Held, 2002).

Di seberang lain, tumbuhnya pola baru dalam hubungan internasional juga dipengaruhi oleh kelahiran globalisasi. Pada mulanya globalisasi adalah perkara ekonomi, dan kini semakin melingkupi berbagai aspek lainnya. Sebagai puncak modernisasi, globalisasi kemudian memunculkan matra baru dalam pergaulan antar bangsa dimana unifikasi (unification) berhadapan dengan fragmentasi (fragmentation), ketidakberdayaan (powerlesness) berhadapan dengan keinginan untuk berbagi (appropriation), otoritas (authority) berhadapan dengan ketidakpastian (uncertainty).

Studi hubungan internasional sendiri sangat dipengaruhi oleh munculnya globalisasi sehingga wacana-wacana tentang "rethinking" mulai tumbuh ke permukaan (Halliday, 1994). Munculnya pandanganpandangan baru dalam studi hubungan internasional didorong karena unit analisis studi ini mengalami perubahan mendasar dalam interdependensi dunia saat ini. Unit analisis lama yang terlalu menekankan "aktor besar" dan formal kini mulai digugat. Hubungan internasional ditandai dengan kehadiran international society yang menyertakan isu, aktor serta pola relasi baru yang sangat mempengaruhi eksplanasi dan deskripsi tentang hubungan internasional.

Robert Keohane mencoba melakukan elaborasi tentang hadirnya masyarakat internasional sebagai ruang sosial-politik yang nyata dalam jaman globalisasi. Wacana international society menempati posisi penting dalam studi hubungan internasional. Menurut Halliday (1994), berbagai perspektif yang tumbuh dalam studi hubungan internasional mulai mengartikulasikan isu international society. Bagi kaum realis, international society mengacu pada relasi antar negara yang didasarkan pada pembagian separangkat norma dan pemahaman antar negara. Pandangan ini misalnya dikemukakan oleh Martin Wright, Hedley Bull, James Mayall dan kalangan teoritisi hubungan internasional dari kubu English School.

Sementara bagi pandangan trans-nasionalis, international society mengacu pada tumbuhnya kekuatan nonstate actors terutama dalam wilayah ekonomi, asosiasi politik, kerjasama kebudayaan, persebaran ideologi yang melampaui batas-batas negara yang kemudian mentransformasikan diri dalam hubungan baru. Inilah yang kemudian membentuk jaringan yang melampaui otoritas negara. Masyarakat internasional tumbuh dari dalanmnya. Pandangan transnasional sangat dipengaruhi secara kuat oleh tradisi behavioralis dan kalangan liberal internationalist seperti John Burton, Robert Keohane dan Joseph Nye. Singkatnya, gagasan tentang international society mencoba melihat dunia sebagai bangunan baru, sebuah kombinasi antara intersocietal and inter-state actors, sebuah homology.

Keohane melihat ada dilema yang harus dihadapi masyarakat internasional dewasa ini. Dalam review-nya terhadap Hobbes, Bertrand Russell (2002) mengemukakan bahwa Hobbes adalah seorang empiris sekaligus rasionalis. Dalam Leviathan - raksasa laut Hobbes mengemukakan makna kedaulatan (sovereignty) sebagai sebuah jiwa tiruan (artificial soul). Pakta dan perjanjian yang dibuat manusia dalam berbagai 
kelompok sosial pada dasarnya ditujukan untuk memunculkan peniruan perilaku. Maka organisasi dibangun, kerjasama dirancang dan pakta dikonstruksi sebagai bentuk kontrak sosial. Leviathan sebenarnya berisi pesimisme Hobbes tentang hubungan manusia yang secara kodrati memiliki superego dalam interaksinya dengan manusia lain. Kedaulatan merupakan kekuasaan tertinggi yang dicapai oleh manusia dan dikompensasikan dalam berbagai unit kerjasama. Kekuasaan kedaulatan, dalam imajinasi Hobbes, sangtat tidak terbatas. Begitu juga dalam kedaulatan, selalu ada si pemilik kedaulatan yang boleh jadi bertindak anarkis atau otoriter. Hobbes sendiri dalam bab lain dari Leviathan mengatakan bahwa kekuasaan negara harus absolut.

Inilah barangkali yang kemudian dipahami Keohane sebagai dilema Hobbes. Dilema Hobbes merupakan sesuatu yang tidak bisa diabaikan dalam hubungan internasional yang makin fragile saat ini Konflik akan senantiasa hadir mengikuti perkembangan masyarakat. Dilema Hobbes menyatakan, pada saat masyarakat memiliki kalkulasi rasional, mementingkan diri sendiri, berorientasi pada hasil dan kejayaan dan memiliki ketakutan lebih pada yang lain, maka keamanan tidak akan tercipta. Tetapi Hobbes kemudian menyatakan bahwa rasionalisme juga akan memunculkan penguasa predator dan negara opresif. Lebih jauh, Keohane mengemukakan bahwa solusi Hobbes hanya akan menciptakan perang di antara sesama. Pandangan Hobbes kemudian dijadikan alat baca untuk melihat semacam kecemburuan kontinental dalam alam globalisasi. Potensi anarki akan tetap ada dalam sistem internasional.

Globalisasi, dalam aras politik, telah memunculkan model "self help system" - sebuah sistem yang menolong dirinya sendiri sebagaimana dikatakan oleh Waltz. Otoritas negara memang mulai hilang, tetapi hal ini bisa diproyeksikan terhadap berbagai sistem internasional baik dalam bidang ekonomi, politik maupun keamanan.

Hadirnya institusi semacam Masyarakat Eropa (EC) merupakan jawaban atas tumbuhnya institusi untuk mengatasi hubungan interdependen. Kehadiran institusi tersebut telah mengubah makna kedaulatan. Kini, keputusan internasional tidak lahir dari negara per se, tetapi ada tumbuh dalam basis global. Keohane kemudian menyatakan bahwa institusi dalam level internasional akan mampu mengatasi tumbuhnya masyarakat internasional yang potensial menimbulkan anarki karena hanya akan melahirkan entitas predator.

Problem dunia saat ini adalah bagaimana kita bisa melakukan aransemen institusi yang konsisten mengatasi problem global dengan problem domestik. Institusi ini tidak mungkin dibentuk oleh melalui pemerintah atau negara, tetapi melalui keterlibatan masyarakat sipil internasional (international civil society), tidak juga dikonstruksi oleh kekuatan hegemonik yang tunggal, tetapi oleh setiap negara yang memiliki kepentingan. Kehadiran masyarakat sipil internasional seperti meningkanya peran kaum bisnis dan profesional, kaum pekerja, yang kini tumbuh baik di negara maju dan negara berkembang. Sistem internasional, menurut Keohane, harus mampu menjadi institusi yang bisa melakukan intermediasi dan pemeliharaan institusi yang ada, melakukan moderasi atas konflik, menciptakan pembuatan keputusan yang koheren untuk menciptakan kemakmuran kolektif dan mempromosikan pertumbuhan ekonomi.

Aktor-aktor baru yang oleh Keohane disebut lahir dari ranah international civil society, bersama negara yang terkoneksi dalam bangunan interdependensi, akan mentransformasikan globalisasi menjadi sebuah ruang sosial-politik baru yang menguntungkan bagi masyarakat internasional. Munculnya international society jelas akan menumbuhkan semacam vulnerabilty of world. Hierarkhi dunia mengalami peluluhan, seperti makin kaburnya problem domestik dan problem internasional. Dalam bahasa Keohane, kita tidak bisa memastikan prediksi tentang dinamika regional yang kini berlangsung.

Kelemahan utama esai Keohane barangkali terletak pada pandangannya yang terlalu melihat proses globalisasi sebagai proses yang dipkonstruksi secara kolektif oleh semua negara dan semua aktor yang tumbuh dalam international society. Kenyataannya, 
globalisasi lebih merupakan politik makna (politic of meaning) yang dilakukan oleh kekuatan-kekuatan raksasa yang berlindung dalam jubah interdependensi global.. Dalam hal ini, Keohane melupakan sisi mode of production dari proses globalisasi yang sampai saat ini tetap memunculkan disparitas ekonomi-politik antara negara Utara dan Selatan serta antara masyarakat maju di negara-negara Barat dengan masyarakat subsisten di negara-negara berkembang. Hadirnya masyarakat internasional tidak selalu berujung pada tumbuhnya hubungan yang setara antar masyarakat dunia. Secara politik dan ekonomi, kehadiran masyarakat internasional hanya ditandai dengan proses berpindahnya pembuatan keputusan dari yang semula oleh negara-negara, kini diproyeksikan dalam berbagai sistem internasional.

\section{LULUHNYA HIERARKHI}

Hadirnya fenomena baru dalam peradaban manusia, menghadirkan apa yang oleh Anthony Giddens disebut "tranformation of intimacy" (Giddens, 1991) sebagai konsuekuensi globalisasi, telah menyentak kesadaran masyarakat modern. Bahwa yang disebut "relations" kini bukan lagi menunjuk pada hubungan antar aktor besar dan dalam konteks ingin menciptakan regulasi, tetapi juga sebuah keintiman baru antar manusia sebagai identitas yang kini memiliki otonominya sendiri. Manusia, per individu, kini bahkan bisa melewati batas-batas kewenangan struktur-struktur besar untuk berinteraksi dengan individu lain. Relasi itu kemudian membentuk apa yang oleh ilmu sosiologi disebut jaringan sosial. Akan tetapi jaringan sosial tersebut kini demikian luas, kompleks dan membentuk kultur baru. Sebuah identitas muncul dari fenomena itu, dan identitas berhubungan dengan struktur-struktur dominan masyarakat modern seperti media. Media kemudian melakukan tafsir dan pembentukkan citra. Citra-citra itu kemudian menjalar kemana-mana, menjadi kultur global yang semua orang bisa mengadaptasi, melawan bahkan menghujatnya. Apa yang disebut fakta tentang politik internasional dengan segala bentuk konstelasinya seperti perang dingin, pasar bebas, liberalisme perdagangan dan seterusnya bukanlah sebuah fakta objektif sebagaimana keyakinan pandangan kaum positivist. Fakta "objektif" hanyalah sebuah kontruksi dari berbagai pihak. Citra tentang suatu fenomena sangat tergantung pada bagaimana si tokoh melakukan pemaknaan serta kontruksi atas fenomena tersebut. Persoalannya bukan terletak pada fenomena yang dihadapi, tetapi bagaimana dan siapa yang melakukan penafsiran dan kontruksi atas suatu fenomena tersebut.

Perubahan-perubahan yang terjadi dalam politik internasional sejak tahun 1990-an, membawa konsekuensi penting terhadap munculnya perspektif baru dalam studi hubungan internasional. Penjelasan lama tentang hubungan antar bangsa mulai mengalami gugatan. Salah satu pandangan yang cukup dominan dan berpengaruh adalah pandangan positivisme. Dalam waktu yang amat panjang, pandangan ini sangat mempengaruhi ilmu sosial, tak terkecuali ilmu hubungan internasional. Pandangan ini berakar pada pemikiran August Comte (1798-1857) yang kemudian mempengaruhi gagasan bercorak modernis dalam ilmu sosial-politik.

Sekurang-kurangnya terdapat empat asumsi dasar dari positivisme. Pertama, logika empirisme. Asumsi ini menyatakan bahwa suatu proposisi hanya memiliki arti sepanjang bisa dibuktikan kebenaranya dengan pengalaman sosial manusia. Kedua, kepercayaan pada objektivitas. Asumsi ini sering dirumuskan "dunia yang kita ketahui, terlepas dari pengetahuan kita terhadapnya". Si peneliti (yang mengetahui) berada dalam garis demarkasi yang tegas dengan yang diteliti (yang diketahui).

Ketiga, reduksionisme. Asumsi ini menyatakan bahwa subjek dapat memecah-mecah objek menjadi satuan-satuan kecil. Generalisasi dibangun dari pengetahuan atas satuan-satuan kecil itu. Perilaku politik luar negeri Amerika (seolah) bisa diketahui dari kasus-kasus tertentu yang kasuistik. Reduksionisme secara nyata ada dalam perumusan hipotesis yang diajarkan dalam metodolodi positivis.

Keempat, asumsi tentang value free of science. Asumsi ini warisan dari filsafat rasionalisme Descartesian. 
Asumsi ini telah menciptakan keangkuhan epistemologis, menyembunyikan ideologi di balik jubah metodologi, serta menggunakan objektivitas sebagai kendaraan untuk melangsungkan penaklukan.

Dalam Methodological Debates:Post Positivist Approach (Jackson and Sorensen, 2003). Jackson dan Sorensen menghadirkan semacam gugatan atas epistemologi dan metodologi dalam studi hubungan internasional.

Keduanya mencoba membuka kemungkinan bagi studi hubungan internasional untuk menggunakan pisau analisis dari teori-teori postpositivist terutama aliran teori kritis, postmodernisme, konstruktivisme dan teori-teori normatif. Teori kontruktivis merupakan generasi kedua dari teori kritis yang ingin menantang pemikiran neorealis dan neoliberal dalam studi hubungan internasional.

Pandangan teori kritis sangat mencurigai tentang netralitas pengetahuan. Pandangan ini digemakan oleh mazhab Franfurt. Secara epistemologis, pandangan ini berakar pada pemikiran neo-marxis. Teori kritis menolak pandangan postivis tentang fakta objektif, distingsi antara subjek dan objek, serta ilmu pengetahuan yang bebas nilai. Ilmu pengetahuan selalu terikat pada struktur dan memiliki pertautan kepentingan karenanya tudak pernah netral baik secara moral maupun secara politik-ideologis.

Dalam konteks hubungan internasional, sistem internasional merupakan hasil kontruksi dari kekuatan dominan. Gagasan tentang "pasar bebas", "globalisasi” serta wacana-wacana global semacam "terorisme", lebih merupakan wacana merkantilis ketimbang menunjuk realitas objektif. Dalam gagasan-gagasan tersebut tumbuh berbagai kepentingan:pasar bebas dan globalisasi sangat berkepentingan dengan good governance di negaranegara berkembang, terorisme sangat berkepentingan dengan ekplorasi negara-negara Barat pada sumber minyak dunia, pasar bebas sangat berkepentingan dengan stabilitas nilai tukar, dan seterusnya. Maka apapun yang lahir dari dalamnya, selalu merupakan hasil proyeksi dari kekuasaan dominan. Inilah yang kemudian melahirkan struktur-struktur dominatif.

Robert Cox, yang dianggap menjadi pelopor teori kritis dalam studi hubungan internasional menyatakan bahwa teori selalu terikat dengan tujuan yang ingin dicapai oleh seseorang. Dalam hubungan antar bangsa, yang kemudian terjadi adalah pertarungan (struggle), dan bukan relasi (relation), paksaan (coersion) dan bukan emansipasi.

Postmodernisme memiliki pikiran yang kurang lebih sama dengan teori kritis. Persamaan itu sekurangkurangnya terletak pada kecurigaan. Jika teori kritis mencurigai selubung kuasa dalam tiap gagasan, kalangan postmodernis mencurigai mistifikasi dalam apa yang disebut cerita-cerita agung (grand narratives). Jika agenda kaum teori kritis adalah emansipasi, kalangan post-modernis mengajukan rekomendasi radikal yakni dekonstruksi. Kalangan ini mencurigai proyek-proyek modern seperti pencerahan (enlightenment) yang berasal dari filsafat rasionalisme Kantian serta kepercayaan berlebihan pada pemikiran positivis tentang ilmu pengetahuan (science). Positivisme, bagi mereka adalah "epitome of intellectual error and academic arrogance"

Dalam konteks hubungan internasional, kalangan postmodernis ingin melakukan pembacaan ulang (rereading) terhadap hasil bacaan dari kalangan positivis yang diartikulasikan secara kuat oleh kalangan realis maupun neo-realis. Kritik postmodernis terhadap kalangan positivis dalam hubungan internasional berpusat pada konsep kedaulatan (sovereignty). Bagi kalangan positivis, kedaulatan merupakan syarat bagi berlangsungnya mekanisme politik. Kalangan postmo mencurigai konsep ini sebagai suatu sinonim belaka dengan kekuasaan negara, penggunaan kekerasan oleh negara, atau dalam term Hobbesian, "a supreme and neccesary authority in a leviathan-less world"(George, 1994).

Fokus lain dari postmodernisme adalah globalisasi. Terminologi ini mengandaikan hubungan setara dan resiprokal antar negara. Dalam faktanya, globalisasi ternyata meunculkan pihak yang kuat (powerfull) dan yang kalah (powerless). Secara ekonomi, globalisasi telah menciptakan ketergantungan baru yang lebih canggih (shopiticated dependency) dibanding fase ketergantungan pada fase sebelumnya. Meminjam bahasa Bauman, "Globalization is not about what we all....wish or hope to do. 
It is about what is happening to us all"(Clark, 1999).

Post-modernisme mengajak kita merayakan keragaman budaya (multikulturalisme). Hubungan internasional tidak semata-mata ditentukan oleh aktor besar seperti Amerika, NATO, PBB serta kekuatan. Juga oleh wacana besar seperti pasar bebas, globalisasi, demokrasi. Setiap entitas di muka bumi punya kontribusinya dalam memperkaya peradaban umat manusia. Isu-isu lain yang semula dianggap remehtemeh seperti endemi suatu penyakit, migrasi manusia, banjir dan kebakaran hutan, hilangnya komunitas lokal (local genius) mulai dijadikan studi yang memiliki dampak luas. Karena itu dikotomi antara politik tinggi (high politic) dan politik rendah (low politic) tidak lagi relevan.

Pemikiran konstuktivis memiliki banyak kesamaan dengan aliran kritis dan post-modernis dalam hal unit analisa. Ketiganya ingin membangun kesadaran baru tentang posisi dan eksistensi aktor dan subjek dalam hubungan antar bangsa. pemikiran konstruktivis. Eksistensi dalam politik dunia hanya berlangsung melalui hubungan antar-aktor. Jadi, eksistensi lahir dari ko-eksistensi. Chris Reus-Smit memasukkan pemikiran konstruksionis ke dalam teori kritis generasi kedua yang menoba melihat fenomena sosial dari politik dunia. Dalam level yang lebih makro, yakni dalam hubungan-hubungan sosial, kaum konstruksionis mengemukakan bahwa masing-masing individu menyumbang bagi terbentuknya fakta dan norma sosial. Hal ini berbeda misalnya dengan prinsip pemikiran kontrak sosial yang cenderung memberi peluang bagi pihak dominan yang menguasai kehidupan.

Kalangan ini meyakini bahwa hubungan internasional dibangun oleh pikiran dan gagasan, dan bukan oleh kondisi material ataupun kekuatan. Tidak ada hukum alamiah yang menggerakan kehidupan politik, ekonomi dan sosial. Begitu juga dengan sejarah (history), yang menurut kalangan ini merupakan proses akumulasi gagasan dan pikiran. Karena itu sejarah relatif adanya. Relatif juga tatanan-tatanan yang menopangnya.

Konstruktivisme bergerak dalam level interpretasi ketimbang eksplanasi. Ilmu pengetahuan, khususnya ilmu sosial, hanya bisa melakukan tafsir atas fenomena, tidak bisa menjelaskan secara objektif suatu fenomena seperti rumusan model kalangan positivis:"jika x..., maka y..”. Suatu fakta akan sangat tergantung pada penafsiran si aktor. Objektivitas sosial tidak lebih dari rutinitas diskursif yang kemudian mendapat pengakuan. Objektivitas, dengan kata lain, adalah subjektivitas yang berulang. Jika semua manusia di muka bumi menyebut Saddam Hussein sebagai penjahat perang, maka secara "objektif" Saddam adalah penjahat perang. Karena itu ia harus dipenjara. Sebaliknya, jika seluruh manusia menyebut Bush sebagai penyelemat dunia, maka secara "objektif" Bush akan menjadi penyelemat dunia. Konstruksi-konstruksi seperti ini bisa berganti, tergantung pada mode of production yang berkembang.

Kajian post-positivist terakhir dalam kedua artikel tersebut adalah teori-teori normatif. Secara historis, aliran normatif sebenarnya bukan post-positivist karena positivisme-rasionalisme merupakan reaksi dari aliran normatif-idealisme. Tetapi kehadiran aliran ini studi hubungan internasional mutakhir lebih banyak didasarkan pada kekecewaan atas pandangan positivist yang menyeret dunia pada anarki dan kekerasan.Aliran normatif lebih mementingan aspek-aspek moral dan sisi manusiawi yang telah hilang pada pemikiran positivis yang lebih mementingkan progress ketimbang kemakmuran, lebih mementingkan pertumbuhan (growth) ketimbang pembangunan (development). Gagasan normatif barangkali tumbuh kembali bersamaan dengan munculnya gerakan-gerakan humanis serta munculnya semangat kosmopolitan dari gerakan-gerakan tersebut untuk menyelematkan dunia. Bersama dengan aliran konstruktivis, aliran normatif sama-sama mengusung gagasan dan pikiran intersubjektif. Bagaimanapun, aliran normatif mencoba melihat kearifan lama sebagai pandangan yang patut dipertimbangkan dalam politik antar bangsa.

\section{KESIMPULAN}

Pemikiran post-positivist berhasil menyajikan 
topeng-topeng epistemologis dari pemikiran positivis. Sekurang-kurangnya, melalui pemikiran kritis, postmodernis, konstruksionis serta aliran normatif, kita disadarkan pada beberapa hal:

- Pertama, terdapat selubung politis dan ideologis dari gagasan-gagasan besar dalam politik dan ekonomi internasional yang semula kita anggap netral, alamiah dan objektif.

- Kedua, aliran post positivist membantu kita untuk sadar tentang proses mistifikasi dari argumen dan janji kaum positivis seperti tentang keadilan, pasar bebas, interdependensi global, dan seterusnya.

- Ketiga, aliran post-positivist mengajak kita untuk melihat fenomena-fenomena kecil yang berdampak besar yang selama ini diabaikan oleh ilmuwan positivist.

- Keempat, aliran post-positivist membantu kita untuk selalu kritis terhadap gagasan yang muncul sebagai gagasan global. Dengan kata lain, kita diajak untuk melakukan emansipasi (critical theory), mendekonstruksi (postmodernisme), menolak hegemoni (konstruksionisme) serta berpikir tentang adanya post-material values dalam politik internasional (aliran normatif).

Meski demikian, aliran post-positivist bukan tanpa kelemahan. Pertama, sebagai suatu perspektif keilmuwan, pemikiran ini tidak memberi batas yang tegas tentang kategori konseptual, model, unit analisa sehingga tidak mudah membuat semacam marka teoritis yang diperlukan untuk kepentingan dunia akademik. Penolakan terhadap semua hal ini menyebabkan pandangan kalangan post-positivist bisa digunakan untuk keperluan apapun dan oleh siapapun.

Kelemahan kedua, pandangan post-positivist, terutama pandangan dekontruksi dari kalangan postmodernis, tidak menyajikan suatu gambaran yang tegas tentang kondisi apa yang ingin dituju dalam tatanan global. Mistifikasi yang diciptakan kalangan kaum positivist pada gilirannya akan digantikan dengan mistifikasi baru model kaum post-modernis.

Ketiga, generalisasi yang berlebihan dan kecurigaan mendalam atas grand narrative hanya akan melahirkan nihilisme ilmu pengetahuan. Meskipun cukup membantu melihat sisi-sisi politis pengetahuan, tetapi pandangan kalangan ini cenderung menolak pada yang serba tertib sehingga semua fakta di dalam politik internasional ditafsirkan sebagai proyek kuasa.

Keempat, logika "setiap entitas adalah aktor yang menentukan" akan cenderung menciptakan suasana yang gaduh dan disorientasi barangkali akan terjadi dalam politik internasional.

Kelima, gagasan post-positivist barangkali berhasil dalam level penafsiran dan pembacaan, tetapi sulit untuk membangun kesadaran bersama dalam rangka melakukan resistensi atas dominasi. Bagaimana mungkin ada kesadaran bersama, jika setiap aktor punya tafsir yang liar dan bebas (dan diijinkan) tentang suatu keadaan. Gagasan post-positivist dari kubu teori kritis dan post-modernis kadang hanya merupakan sikap akademik ketimbang sebuah alat analisis baru bagi fenomena hubungan internasional. ${ }^{* *}$

\section{REFERENSI}

Anthony Giddens, Modernity and Self Identity, Stanford University, 1991

Evan Luad, Basic Text in International Relations, MacMillan, 1992 Anthony Giddens, Modernity and Self-Identity, Stanford, 1991 , The Third Way, Blackwell, 1998.

Bertand Russell, Sejarah Filsafat Barat, Pustaka Pelajar, 2002. David Held dan Anthony McGrew, Global Transformations, Stanford University, 1999

Transformations Reader, Polity Press, 2000

Fred Halliday, Rethinking of International Relations, MacMillan, 1994.

Ian Clark, Globalization and International Relations Theory, Oxford University, 1999.

Jim Geogre, Discourse of Global Politics, Lynne Publisher, Colorado, 1994.

Robert W Cox, Production, Power and World Order, Columbia University, 1987

Stephanie G Neuman (ed), International Relations Theory and The Third World, MacMillan, 1998. 